\title{
TINJAUAN YURIDIS PERTANGGUNG JAWABAN RUMAH SAKIT ATAS KE IKUT SERTAAN DALAM PROGRAM BADAN PENYELENGGARA JAMINAN SOSIAL (BPJS) KESEHATAN
}

\begin{abstract}
Ariawan Gunadi
(Dosen tetap Program Magister Ilmu Hukum pada Fakultas Hukum Universitas Tarumanagara, Meraih Sarjana Hukum (S.H) pada Fakultas Hukum Universitas Tarumanagara, Magister Ilmu Hukum pada Fakultas Hukum Universitas Islam Jakarta dan Meraih Doktor Ilmu Hukum pada

Fakultas Hukum Universitas Indonesia)

(E-mail: ariawangun@gmail.com)
\end{abstract}

\section{Ida Nursida}

(Mahasiswa Program Magister Ilmu Hukum, Fakultas Hukum Universitas Tarumanagara)

Received: 22 April 2019; Accepted: 29 Mei 2019; Published: 10 Juni 2019

\begin{abstract}
The Social Security Administering Body (BPJS) is a public legal entity formed to organize a social security program. Social Security Agency can alleviate the burden of society in obtaining health services in hospitals or clinics. This is in accordance with Article 5 Paragraph (1) and Paragraph (2) of Law No.36 Year 2009 on Health. and Article 47 Regulation of Health BPJS No.1 Year 2014 on the implementation of Health Insurance. As an insurance company BPJS health ensures the implementation of health programs

Hospitals and Clinics as health service providers in demand by the government to play an active role in providing good health services to the community according to its function, in accordance with Law Number 44 Year 2009 on Hospital. But even if the hospital or health service supports the social health insurance program or BPJS is proved by the poster that the Hospital or Clinic receive BPJS patients, does not mean that the service received by the community is in line with expectations.
\end{abstract}

Keywords: Accountability, Hospital, BPJS Health

\section{PENDAHULUAN.}

\section{A. LATAR BELAKANG}

Badan kesehatan dunia (WHO) telah menetapkan bahwa kesehatan merupakan investasi, dan kewajiban setiap manusia,kutipan tersebut juga tertuang dalam Pasal 28 huruf (h)

Undang-Undang Dasar 1945 selanjutnya disingkat dengan (UUD 
NRI) ${ }^{1}$ dan Undang-Undang Nomor 36

Tahun 2009 tentang Kesehatan selanjutnya disingkat (UUK),

"Bahwa kesehatan merupakan hak asasi manusia dan salah satu unsur kesejahteraan yang harus diwujudkan sesuai dengan cita-cita bangsa Indonesi sebagaimana dimaksud dalam Pancasila dan UndangUndand Dasar 1945,"

Sebelumnya telah lahir ketetapan MPR Nomor XVII/MPRRI/1999 dan UndangUndang Nomor 39 Tahun 1999 tentang Hak Asasi Manusia semakin menguatkan perubahan paradigma tersebut dimana pemerintah bertanggung jawab mengatur agar terpenuhi hak hidup sehat bagi penduduknya termasuk masyarakat miskin dan tidak mampu.

Pemerintah Indonesia telah melakukan berbagai upaya dalam memenuhi hak setiap warga negaranya untuk mendapatkan pelayanan kesehatan yang layak. Terbukti dengan adanya Undang-

${ }^{1}$ Undang-Undang Dasar 1945 Pasal 28 huruf (h) “ Setiap orang berhak hidup sejahtera lahir dan batin, bertempat tingal, dan mendapatkan lingkungan hidup yang baik dan sehat serta berhak memperoleh pelayanan kesehatan."
Undang Nomor 40 Tahun 2004 tentang Sistem Jaminan Sosial

Nasional $^{2}$. Walaupun ini mungkin merupakan perubahan yang mendasar bagi perasuransian di Indonesia khususnya Asuransi Sosial dimana salah satu program jaminan adalah asuransi kesehatan.

Pelayanan kesehatan merupakan salah satu upaya yang dapat dilakukan untuk meningkatkan derajat kesehatan baik perorangan maupun kelompok atau masyarakat secara keseluruhan, dan itu tentu dilakukan di rumah sakit atau klinik sebagai fasilitas pemberi jasa pelayanan kesehatan sesuai dengan ukuran atau standard perawatan kesehatan. Pembangunan kesehatan merupakan pembangunan nasional maka pemerintah sebagai institusi tertinggi yang bertanggung jawab atas pemeliharaan kesehatan harus

\footnotetext{
${ }^{2}$ Undang-Undang Nomor 40 Tahun 2004 Pasal 19 Ayat (2) "bahwa Jaminan kesehatan diselengarakan dengan tujuan agar peserta memperoleh manfaat pemeliharaan kesehatan dan perlindungan dalam memenuhi kebutuhan kesehatan dasar, hal ini merupakan salah satu bentuk atau cara agar masyarakat dapat dengan mudah melakukan akses ke fasilitas kesehatan atau mendapatkan pelayanan kesehatan."
} 
memenuhi kewajiban dalam penyediaan sarana pelayanan kesehatan.Pelaksanaan pembangunan di bidang kesehatan melibatkan seluruh warga negara Indonesia, karena pembangunan kesehatan mempunyai hubungan yang dinamis dengan sektor lainnya. ${ }^{3}$

Undang-Undang Dasar Republik Indonesia Tahun 1945 Pasal $28 \mathrm{H}$ ayat 3 menjelaskan bahwa setiap warga Indonesia berhak atas jaminan sosial yang memungkinkan pengembangan dirinya secara utuh sebagai manusia yang bermartabat, dan dalam Pasal 34 ayat 3 dijelaskan bahwa tanggung jawab negara adalah menyediakan fasilitas pelayanan kesehatan dan fasilitas pelayanan umum yang layak. Undang-Undang Nomor 36 Tahun 2009 tentang Kesehatan yang mengamanatkan bahwa upaya pemenuhan kebutuhan salah satu hak dasar warga negara dan negara bertanggung jawab untuk mengatur dan memastikan bahwa hak

\footnotetext{
${ }^{3}$ Suharto. Edi, Kemiskinan dan Perlindungan Sosial di Indonesia, Menggagas Model JaminanSosial Universal Bidang Kesehatan., (Bandung:Alfabeta, 2009),34-67.
}

untuk hidup sehat bagi seluruh warga negara dipenuhi termasuk bagi warga negara dan/atau tidak mampu.

Pembangunan kesehatan diarahkan untuk meningkatkan kesadaran, kemauan dan kemampuan hidup sehat bagi setiap orang agar peningkatan derajat kesehatan warga di suatu negara yang setinggitingginya dapat terwujud. UndangUndang tersebut menegaskan bahwa seluruh warga negara mempunyai hak yang sama dalam memperoleh akses atas sumber daya di bidang kesehatan dan memperoleh pelayanan kesehatan yang aman, bermutu, dan terjangkau

Pemerintah Indonesia telah melakukan berbagai upaya dalam memenuhi hak setiap warga negaranya untuk mendapatkan pelayanan kesehatan yang layak. Terbukti dengan adanya UndangUndang Nomor 40 Tahun 2004 tentang Sistem Jaminan Sosial Nasional ${ }^{4}$. Walaupun ini mungkin

\footnotetext{
${ }^{4}$ Undang-Undang Nomor 40 Tahun 2004 Pasal 19 Ayat (2) "bahwa Jaminan kesehatan diselengarakan dengan tujuan agar peserta memperoleh manfaat pemeliharaan kesehatan dan perlindungan dalam memenuhi kebutuhan kesehatan
} 
merupakan perubahan yang mendasar bagi perasuransian di Indonesia khususnya Asuransi Sosial dimana salah satu program jaminan adalah asuransi kesehatan.

Badan Penyelenggara Jaminan Sosial (BPJS) adalah badan hukum publik yang dibentuk untuk menyelenggarakan program jaminan sosial $^{5}$. Badan Penyelengara Jaminan Sosial ini dapat meringankan beban masyarakat dalam mendapatkan pelayanan kesehatan di Rumah Sakit ataupun klinik. Hal ini sesuai dengan Pasal 5 Ayat (1) dan Ayat Undang-Undang No.36 Tahun 2009 tentang Kesehatan. dan Pasal 47 Peraturan BPJS kesehatan No.1 Tahun 2014 tentang penyelenggaraan Jaminan Kesehatan. ${ }^{6}$ Sebagai

dasar, hal ini merupakan salah satu bentuk atau cara agar masyarakat dapat dengan mudah melakukan akses ke fasilitas kesehatan atau mendapatkan pelayanan kesehatan."

${ }^{5}$ Pasal 7 Undang-Undang Nomor 24 Tahun 2011 Tentang Badan Penyelenggara Jaminan Sosial.

${ }^{6}$ Undang-Undang Nomor 36 Tahun 2009 Pasal 5 Ayat (1) "setiap orang mempunyai hak yang sama dalam memperoleh akses atas sumber daya dibidang kesehatan dan ayat (2), setiap orang mempunyai hak dalam memperoleh pelayanan kesehatan yang aman, bermutu dan terjangkau”. perusahaan asuransi BPJS kesehatan menjamin penyelenggaraan program kesehatan .

Rumah Sakit dan Klinik sebagai penyelenggara pelayanan kesehatan di tuntut oleh pemerintah agar turut berperan aktif dalam memberikan pelayanan kesehatan yang baik terhadap masyarakat sesuai fungsinya, sesuai Undang-Undang Nomor 44 Tahun 2009 tentang Rumah Sakit. ${ }^{7}$ Namun sekalipun Rumah Sakit atau pelayanan kesehatan tersebut mendukung adanya program jaminan sosial kesehatan atau BPJS dibuktikan dengan adanya poster-poster bahwa Rumah Sakit atau Klinik tersebut menerima pasien BPJS, bukan berarti pelayanan yang diterima oleh masyarakat sudah sesuai dengan pengharapan. Banyaknya kasus mengenai penolakan pelayanan kesehatan yang

\footnotetext{
${ }^{7}$ Undang-Undang Nomor 44 Tahun 2009 tentang Rumah Sakit "rumah sakit adalah institusi pelayanan kesehatan yang menyelenggarakan pelayanan kesehatan perorangan secara paripurna yang menyediakan pelayanan rawat inap, rawat jalan, dan gawat darurat."
} 
diterima peserta BPJS bukan lagi hal yang baru, sejak berlakunya sistem Jaminan Kesehatan Nasional (JKN) yang diselenggarakan oleh Badan Penyelenggara Kesehatan Nasional (BPJS) Kesehatan. Program tersebut diluncurkan pemerintah Per 1 Januari 2014.dan selama perjalanannya, sejumlah persoalan pun muncul di masyarakat. Banyak Rumah Sakit menolak pasien peserta Badan Penyelenggara Jaminan Sosial (BPJS) dengan alasan ruangan perawatan penuh.

Harapan masyarakat akan pelayanan kesehatan yang optimal belum dirasakan, masih saja banyaknya kasus penolakan yang dilakukan pihak Rumah Sakit ataupun Klinik kerapkali terjadi, berbagai bentuk penolakan mulai dari tempat yang sesuai dengan jaminan, dikatakan tidak ada atau penuh, mungkin tempat ada tetapi pihak Rumah Sakit membatasi bagi peserta BPJS sehingga dikatakan penuh, penolakan juga terjadi karena tidak adanya sarana prasarana / tidak tersedianya fasilitas rawat inap khusus seperti ICU, ICCU, sehingga penderita harus mengalami rujukan ketempat yang mempunyai fasilitas tersebut.

\section{B. PERUMUSAN MASALAH}

Penulis merumuskan masalah ini sebagai berikut:

1. Bagaimana tinjauan yuridis bagi Rumah Sakit yang tidak ikut dalam program BPJS Kesehatan.

2. Bagaimana pertanggung jawaban Rumah Sakit dalam menyediakan fasilitas layanan kesehatan bagi pasien peserta BPJS jika ada pembatasan kuota dalam pelaksanaan pelayanan.

Undang-Undang Nomor 36 Tahun $2009 \quad$ Tentang Kesehatan yang mengamanatkan Rumah Sakit tidak boleh menolak pasien yang membutuhkan pelayanan Gawat Darurat. ${ }^{8}$

8 Yono Maulana, "Rumah Sakit Wajib Melayani Peserta BPJS", kompasiana.com. 14 Juni 2016, 15. 


\section{PEMBAHASAN}

A. Tinjauan yuridis bagi Rumah Sakit yang tidak ikut dalam program BPJS Kesehatan.

Pertanggungjawaban Rumah Sakit atas keikut sertaannya dalam program Badan Penyelenggara Jaminan Sosial (BPJS), dalam menghadapi era BPJS tidaklah mudah, terlebih untuk Rumah Sakit, perlu pemikiran, strategi, pengertian, kesepahaman dan kesepakatan bersama diseluruh internal Rumah Sakit. Rumah Sakit dituntut harus memiliki hubungan harmonis dengan mitra kunci atau mitra utama, dalam hal ini mitra utama Rumah Sakit adalah Pemerintah.

Perlu diketahui kedudukan rumah sakit pada saat sekarang berbeda jauh dengan kedudukannya terdahulu yang dimana rumah sakit tidak bisa dimintai tanggung jawab hukum pidana dikarenakan rumah sakit masih dianggap sebagai lembaga sosial (doctrin of charitable immunity) yang apabila diminta tanggung jawab hukum pidana, maka akan mengurangi kemampuan menolong pasien. Sampai saat ini tercatat beberapa Rumah Sakit sebagai Fasilitas Kesehatan swasta yang menjadi Rumah sakit rujukan BPJS di daerah Jakarta dan telah ikut serta dalam Program Badan Penyelenggara Jaminan Sosial (BPJS) Kesehatan. Dari 189 Rumah Sakit yang ada di Jakarta, baru 91 Rumah Sakit yang bermitra dengan Badan Penyelenggara Jaminan Sosial (BPJS) Kesehatan. ${ }^{9}$ Dan baru sekitar 64 tercatat jumlah Rumah Sakit swasta yang ada di Jakarta sebagai mitra Badan Penyelenggara Jaminan Sosial (BPJS) Kesehatan dari jumlah Rumah Sakit Swasta secara keseluruhan yang ada di Jakarta. ${ }^{10}$ Sanksi Rumah Sakit yang menolak turut serta dalam program BPJS pernah dengan tegas di ungkapkan oleh Presiden Republik Indonesia saat ini, Presiden Joko Widodo mengatakan bahwa Rumah Sakit Swasta yang tidak mau bekerjasama atau melayani pasien

\begin{tabular}{|c|}
\hline $\begin{array}{l}9 \\
\text { http://dinkes.jakarta.go.id/ } \\
(11 / 9 / 2017) . \\
{ }^{10} \mathrm{ibid}\end{array}$ \\
\hline
\end{tabular}


BPJS akan dikenakan sanksi, seperti pencabutan ijin operasional. Ini sesuai dengan Undang-Undang Nomor 36 Tahun 2009 Tentang Kesehatan yang mengamanatkan Rumah Sakit tidak boleh menolak pasien yang membutuhkan pelayanan Gawat Darurat. ${ }^{11}$ Sebagaimana pada Pasal 32 ayat (2) bahwa dalam keadaan darurat, fasilitas pelayanan kesehatan, baik pemerintah maupun swasta dilarang menolak pasien dan/ atau meminta uang muka. ${ }^{12}$ Selain itu, tenaga kesehatan juga wajib memberikan pertolongan pada keadaan gawat darurat. ${ }^{13}$

$$
\text { Kemudian Pasal } 47 \text { ayat }
$$

(1) Peraturan Badan Penyelenggara Jaminan Sosial Kesehatan Nomor 1 Tahun 2014 tentang Penyelenggaraan

\footnotetext{
11 Yono Maulana, "Rumah Sakit Wajib Melayani Peserta BPJS”, kompasiana.com. 14 Juni 2016, 15.

12 Undang-Undang Nomor 36 Tahun 2009 Tentang Kesehatan.

13 Pasal 59 ayat (1) Undang-Undang Nomor 36 Tahun 2014 tentang Tenaga Kesehatan (UU Tenaga Kesehatan, bahwa tenaga kesehatan yang menjalankan praktik pada fasilitas pelayanan kesehatan wajib memberikan pertolongan pertama kepada penerima pelayanan kesehatan dalam keadaan gawat daruratdan/atau pada bencana untuk penyelamatan nyawa dan pencegahan kecacatan.
}

Jaminan Kesehatan(Peraturan BPJS 1/2014) yang menyebutkan setiap peserta Jaminan Kesehatan berhak memperoleh pelayanan kesehatan yang mencakup pelayanan promotif, preventif, kuratif, dan rehabilitatif termasuk pelayanan obat dan bahan medis habis pakai sesuai dengan kebutuhan medis yang diperlukan. Pelayanan kesehatan yang dijamin oleh BPJS Kesehatan terdiri atas: ${ }^{14}$

1. pelayanan kesehatan pada fasilitas kesehatan tingkat pertama;

2. pelayanan kesehatan pada fasilitas kesehatan tingkat lanjutan;

3. pelayanan gawat darurat;

4. pelayanan obat, alat kesehatan, dan bahan medik habis pakai;

5. pelayanan ambulance;

6. pelayanan skrining kesehatan; dan

7. pelayanan kesehatan lain yang ditetapkan oleh Menteri.

\footnotetext{
${ }^{14}$ Pasal 47 ayat (3) Peraturan BPJS Nomor 1 Tahun 2014
} 
Didalam Pasal 63 Peraturan BPJS Nomor 1 Tahun 2014, pelayanan gawat tersebut di atas dapat dilakukan darurat sesuai dengan indikasi medis pelayanan gawat darurat. Pelayanan gawat darurat merupakan pelayanan kesehatan yang harus diberikan secepatnya untuk mencegah kematian, keparahan, dan/atau kecacatan, sesuai dengan kemampuan fasilitas kesehatan dengan kriteria tertentu sesuai dengan peraturan perundang-undangan. Fasilitas kesehatan yang tidak bekerjasama dengan BPJS Kesehatan harus segera merujuk ke fasilitas kesehatan yang bekerjasama dengan BPJS Kesehatan setelah keadaan daruratnya teratasi dan pasien dalam kondisi dapat dipindahkan. ${ }^{15}$

Didalam lampiran Bab IV Huruf A angka 3 Peraturan Menteri Kesehatan Nomor 40 Tahun 2012 tentang Pedoman Pelaksanaan Program Jaminan Kesehatan Masyarakat, disebutkan bahwa pada keadaan gawat darurat (emergency), seluruh fasilitas kesehatan baik jaringan Jaminan
Kesehatan Masyarakat ("Jamkesmas") atau bukan, wajib memberikan pelayanan penanganan pertama kepada peserta Jamkesmas. Bagi fasilitas kesehatan yang bukan jaringan Jamkesmas, pelayanan tersebut merupakan bagian dari fungsi sosial fasilitas kesehatan, selanjutnya fasilitas kesehatan tersebut dapat merujuk ke fasilitas kesehatan jaringan fasilitas kesehatan Jamkesmas untuk penanganan lebih lanjut. Berarti meskipun suatu rumah sakit (sebagai fasilitas kesehatan) tidak bekerja sama dengan BPJS Kesehatan, rumah sakit tidak boleh menolak pasien dalam keadaan darurat dan wajib memberikan pelayanan penanganan pertama kepada pasien peserta BPJS Kesehatan. Karena pelayanan tersebut merupakan bagian dari fungsi sosial fasilitas kesehatan. Setelah keadaan darurat teratasi dan pasien dalam kondisi dapat dipindahkan, fasilitas kesehatan tersebut harus segera merujuk ke fasilitas kesehatan yang bekerja sama dengan BPJS

${ }^{15}$ Ibid, Pasal 63 ayat (4) 
Kesehatan. ${ }^{16}$ Dengan dasar hukum dari pasal-pasal tersebut diatas, maka jika terjadi pelanggaran akan dikenakan sanksi pidana yang mengacu pada Pasal 190 ayat (1) dan ayat (2) Undang-Undang Nomor 36 Tahun 2009 Tentang Kesehatan. ${ }^{17}$

Pimpinan rumah sakit atau tenaga kesehatan yang menolak pasien yang berada dalam keadaan darurat dapat dipidana penjara dan dikenakan denda sebagaimana berikut:

(1) Pimpinan fasilitas pelayanan kesehatan dan/atau tenaga kesehatan yang melakukan praktik atau pekerjaan pada fasilitas pelayanan kesehatan yang dengan sengaja tidak memberikan pertolongan pertama terhadap pasien yang dalam keadaan gawat darurat sebagaimana dimaksud dalam Pasal 32 ayat (2) atau Pasal 85 ayat (2) dipidana dengan pidana penjara paling lama 2 (dua) tahun dan denda paling banyak Rp200.000.000,00 (dua ratus juta rupiah).

${ }^{16} \mathrm{http}: / /$ static.hukumonline.com

17 Yono Maulana, Alasan RS Swasta Belum Mau Bermitra dengan BPJS, https://kompasiana.com., 14 Juni 2016, 15
(2) Dalam hal perbuatan sebagaimana dimaksud pada ayat

(1) mengakibatkan terjadinya kecacatan atau kematian, pimpinan fasilitas pelayanan kesehatan dan/atau tenaga kesehatan tersebut dipidana dengan pidana penjara paling lama 10 (sepuluh) tahun dan denda paling banyak Rp1.000.000.000,00 (satu miliar rupiah).

Jelas sudah aturan hukum bagi pemberi pelayanan kesehatan disini adalah Rumah Sakit baik swasta dan terutama pemerintah dan pemerintah daerah, baik yang sudah bekerja sama dengan BPJS maupun belum, dilarang menolak memberikan pelayanan kesehatan, baik dalam keadaan gawat darurat ataupun tidak, jika melakukan maka akan terkena sanksi seperti sanksi administrasi berupa teguran, teguran tertulis, tidak diperpanjang izin operasional, dan/ atau denda dan pencabutan izin.

Mengacu Undang-Undang Nomor 44 Tahun 2009 Tentang Rumah Sakit Pasal 32 huruf $q$ Undang-Undang Rumah Sakit menyebutkan salah satu hak pasien yakni menggugat dan/ atau menuntut 
Rumah Sakit apabila Rumah Sakit diduga memberikan pelayanan yang tidak sesuai dengan standar. ${ }^{18}$

A. Bagaimana pertanggung jawaban Rumah Sakit dalam menyediakan fasilitas layanan kesehatan bagi pasien peserta BPJS jika ada pembatasan kuota dalam pelaksanaan pelayanan.

$$
\begin{aligned}
& \text { Jika dilihat Rumah Sakit } \\
& \text { adalah sebagai organisasi } \\
& \text { penyelenggara pelayanan publik } \\
& \text { yang mempunyai tanggung jawab } \\
& \text { publik atas setiap pelayanan jasa } \\
& \text { publik kesehatan yang } \\
& \text { diselenggarakannya. Maka tanggung } \\
& \text { jawab publik Rumah Sakit adalah } \\
& \text { menyelenggarakan pelayanan } \\
& \text { kesehatan yang bermutu dan } \\
& \text { terjangkau berdasarkan prinsip } \\
& \text { aman, menyeluruh, non } \\
& \text { diskriminatif, partisipatif dan } \\
& \text { memberikan perlindungan bagi } \\
& \text { masyarakat sebagai pengguna jasa } \\
& \text { pelayanan kesehatan (health }
\end{aligned}
$$

18 Pasal 32 huruf q tentang hak pasien, menggugat dan atau menuntut Rumah Sakit apabila Rumah Sakit diduga memberikan pelayanan yang tidak sesuai standar baik secara perdata ataupun pidana; dan receiver), juga bagi penyelenggara pelayanan kesehatan demi untuk mewujudkan derajat kesehatan masyarakat yang setinggi-tingginya.

Rumah Sakit adalah subyek hukum.berarti, Rumah Sakit dapat melakukan hubungan dengan subyek hukum lainnya dalam melaksanakan pelayanan kesehatan. Karena itu Rumah sakit wajib menanggung segala konsekuensi hukum yang timbul sebagai akibat dari perbuatannya atau perbuatan orang lain yang berada dalam tanggung jawabnya.

Tanggung jawab hukum tersebut meliputi tiga aspek yaitu hukum perdata, hukum administrasi dan hukum pidana. Dari hukum perdata, pertanggungjawaban rumah sakit terkait dengan hubungan hukum yang timbul antara pasien dengan Rumah sakit dalam pelayanan di Rumah Sakit.

Tanggung jawab Rumah Sakit terhadap pasien dalam jasa pelayanan kesehatan adalah terlebih dahulu terletak pada direktur Rumah Sakit sebagai pelaku usaha. Hal ini 
sesuai dengan ketentuan Pasal 19 Undang-Undang Perlindungan

Konsumen Nomor 8 Tahun 1999

Tentang Perlindungan Konsumen.

Penerapan doktrin hospital liability menjadikan Rumah Sakit dapat dimintakan pertanggungjawaban perdata (ganti rugi) yang ditimbulkan orang yang ada dibawah perintahnya. Jadi ada hubungan hukum antara Rumah Sakit dan pasien. Semua tanggung jawab atas pekerjaan tenaga kesehatan adalah menjadi beban tanggung jawab Rumah sakit tempat mereka bekerja. Ketika pasien haknya terabaikan oleh pihak Rumah Sakit maka pasien sebagai konsumen dapat menuntut haknya melalui jalur pengadilan yaitu melalui peradilan umum dan diluar pengadilan dengan alternatif penyelesaian sengketa seperti mediasi, konsilisi, dan arbitrase.

Dengan adanya perjanjian kerjasama antara Rumah Sakit dengan BPJS, maka segala yang menjadi kebutuhan peserta BPJS dalam hal ketersediaan fasilitas pelayanan kesehatan khususnya ruang rawat inap adalah menjadi tangung jawab Rumah Sakit sebagai pemberi pelayanan kesehatan.

Sering adanya keluhan dari peserta BPJS yang merasa ada perlakuan diskriminasi manakala harus di rawat inap, tetapi pihak pemberi pelayanan kesehatan mengatakan "tempat penuh", walaupun ketika di cek ternyata tempat yang dimaksud ada, tidak terisi atau belum terisi pasien lain. Kejadian ini telah dibuktikan oleh pihak Ombudsman sendiri, ketika mengecek, ternyata kamar ada. ${ }^{19}$ Perlu diketahui bahwa pasien juga merupakan subyek hukum yang kepentingannya dilindungi oleh hukum. Pasien merupakan konsumen yang menggunakan jasa pelayanan kesehatan di Rumah Sakit. Dalam pelayanan medis yang dimaksud hal ini adalah pasien, dalam buku hukum kedokteran bahwa pasien adalah orang sakit yang membutuhkan bantuan untuk

${ }^{19}$ Yoga Sukmana, RS Kerap Bilang Ruangan Penuh untuk Pasien BPJS, Ini Penjelasan Ombudsman, Kompas.com, 2017, 15. 
menyembuhkan penyakit yang dideritanya, dan pasien diartikan juga adalah orang sakit yang awam mengenai penyakitnya. ${ }^{20}$

Pasien Rumah Sakit adalah konsumen, sehingga secara umum pasien dilindungi dengan UndangUndang Nomor 8 Tahun 1999 Tentang Perlindungan Konsumen (UU Perlindungan Konsumen), ada didalam Pasal 4 Undang-Undang Nomor 8 Tahun 1999 tentang Perlundungan konsumen dan di dalam Pasal 52 Undang-Undang Nomor 29 Tahun 2004 Tentang Praktek Kedokteran. Apabila hakhak tersebut dilanggar, maka upaya hukum yang tersedia adalah:

1. Mengajukan gugatan kepada pelaku usaha, baik kepada lembaga peradilan umum maupun kepada lembaga yang secara khusus berwenang menyelesaikan sengketa antara konsumen dan pelaku usaha (Pasal 45 UUPK).

2. Melaporkan kepada polisi atau penyidik lainnya. Hal ini karena

20 Wila Chandrawila Supriadi, Hukum Kedoktean, (Bandung: Mandra Maju, 2001), 20. di setiap undang-undang yang disebutkan diatas terdapat kentuan sanksi pidana atas pelanggaran hak-hak pasien.

Perlindungan hak pasien juga tercantum dalam Pasal 32 Undang-Undang Nomor 44 Tahun 2009 Tentang Rumah Sakit yaitu:

a. Memperoleh informasi mengenai tata tertib dan peraturan yang berlaku di Rumah Sakit.

b. Memperoleh informasi tentang hak dan kewajiban pasien.

c. Memperoleh layanan yang manusiawi, adil, jujur, dan tanpa diskrimasi.

d. Memperoleh layanan kesehatan yang bermutu sesuai dengan standar profesi dan standar prosedur operasional.

e. Memperoleh layanan yang efektif dan efisien sehingga pasien terhindar dari kerugian fisik dan materi.

Jika dilihat dari sudut pandang bahwa Rumah Sakit sebagai korporasi Rumah Sakit adalah organisasi 
penyelenggara pelayanan publik, mempunyai tanggung jawab publik atas setiap pelayanan jasa publik kesehatan yang diselenggarakannya. Tanggug jawab publik Rumah Sakit yaitu menyelenggarakan pelayanan kesehatan yang bermutu, terjangkau, berdasarkan prinsif aman, menyeluruh, non diskriminatif, partisipatif dan memberikan perlindungan bagi masyarakat sebagai pengguna jasa pelayanan kesehatan (health receiver) demi untuk mewujudkan derajat kesehatan yang setinggi-tingginya. ${ }^{21}$

1. Tanggung jawab publik Rumah sakit sebagai penyelenggara pelayanan publik diatur dalam ketentuan Pasal 15 UndangUndang Nomor 25 Tahun 2009 Tentang Pelayanan publik yaitu yang mengatur tentang tujuan pelaksanaan pelayanan publik antara lain:

a. Terwujudnya batasan dan hubungan yang jelas tentang

${ }^{21}$ Syahrul Machmud, Rumah Sakit Sebagai Penyelenggara Pelayanan Publik, (Jakarta: Raja Grafindo Perkasa, 2012) ,61. hak, tanggung jawab, kewajiban dan kewenangan seluruh pihak yang terkait dengan penyelenggara pelayanan publik.

b. Terwujudnya sistem penyelenggaraan pelayanan yang layak sesuai dengan asasasas umum pemerintahan dan korporasi yang baik.

c. Terpenuhinya penyelenggaraan pelayanan publik sesuai dengan peraturan perundang-undangan.

d. Terwujudnya perlindungan dan kepastian hukum bagi masyarakat dalam penyelenggaran pelayanan publik.

2. Rumah Sakit sebagai sebuah korporasi menurut hukum perdata merupakan legal person (rechtsperson) yaitu badan hukum yang sifatnya legal personality. Pada awalnya, pembuat undangundang pidana berpandangan hanya manusia yang dapat menjadi subjek tindak pidana, namun seiring perkembangan zaman, korporasi juga bisa menjadi subjek tindak pidana. 
Dalam hukum perdata, pengertian korporasi lebih sempit dari pengertian yang sama dalam hukum pidana, dimana yang pertama hanya membatasi pada pengertian korporasi sebagai badan hukum, seperti perseroan terbatas. Sedangkan yang kedua memperluas makna korporasi tidak hanya terbatas pada badan hukum tapi juga badan usaha seperti CV.

Rumusan pertangungjawaban korporasi tersebut merupakan hal baru yang mengatur dengan tegas bahwa korporasi bertanggung jawab terhadap kerugian sebagai akibat kelalaian tenaga kesehatan yang bekerja padanya. Latar belakang rumusan pertanggungjawaban tersebut bertujuan untuk melindungi kepentingan pasien yang sering kali diabaikan karena faktor kelemahan informasi dan penguasaan hal medis. Pasal 46 Undang-Undang Nomor 44 Tahun 2009 sebenarnya mengatur batasan sampai sejauh mana Rumah Sakit bertanggung jawab yaitu pada kelalaian oleh tenaga kesehatan yang dilarang dalam Undang-Undang.

Munculnya tanggung jawab Rumah sakit awalnya diakibatkan oleh penerapan langah-langkah manajerial yang kurang tepat seperti:

a. Hospital equitment, supplies, medication and food

b. Hospital environment

c. Safety procedures

d. Selection and retention of employees and conferral of staff privilleges

e. resposibilities fo supervision of patient care.

Sedangkan dasar hukum pertanggungjawaban Rumah Sakit dalam pelayanan kesehatan terhadap pasien yaitu adanya hubungan antara Rumah sakit sebagai penyelenggara pelayanan kesehatan, dan pasien sebagai pengguna pelayanan kesehatan.

Rumah Sakit perlu melihat kembali dan menyadari tentang asas dan tujuan Rumah Sakit, bahwa Rumah Sakit diselenggarakan berasaskan Pancasila dan didasarkan 
kepada nilai kemanusiaan, etika dan profesionalitas, manfaat, keadilan, persamaan hak, dan antidiskriminasi, pemerataan, perlindungan dan keselamatan pasien, serta mempunyai fungsi sosial. $^{22}$ Disini pasien juga dilindungi mengenai hak-haknya, sebagaimana dalam Pasal 32 huruf c Undang-Undang Republik Indonesia Nomor 44 Tahun 2009 Tentang Rumah Sakit dijelaskan setiap pasien mempunyai hak memperoleh layanan yang manusiawi, adil, jujur dan tanpa diskriminasi. Jika Pasal-Pasal tersebut dilanggar maka pasien berhak menggugat sesuai Pasal 32 huruf $\mathrm{q}$ dan $r$ Undang-Undang Republik Indonesia Nomor 44 Tahun 2009 Tentang Rumah Sakit, sebagai berikut:

Huruf $q$, bahwa setiap pasien mempunyai hak untuk menggugat dan/ atau menuntut Rumah Sakit apabila Rumah Sakit diduga memberikan pelayanan yang tidak sesuai dengan standar baik secara perdata maupun pidana; dan

Huruf $r, \quad$ mengeluhkan pelayanan Rumah Sakit yang tidak sesuai dengan standar pelayanan

22 Pasal 2 Undang-Undang Republik Indonesia Nomor 44 Tahun2009 Tentang Rumah Sakit. melalui media cetak dan elektronik sesuai dengan ketentuan perundangundangan.

Jika terjadi pelanggaran dalam pasal ini maka akan dikenakan sanksi sebagaimana dalam Pasal 29 ayat (2) Undang-Undang Nomor 44 Tahun 2009 Tentang Rumah Sakit.yaitu:

Pelanggaran atas kewajiban sebagaimana dimaksud pada ayat (1) dikenakan sanksi administratif berupa:

1) Teguran;

2) Teguran tertulis; atau

3) Denda dan pencabutan izin Rumah Sakit.

\section{PENUTUP}

Berdasarkan uraian serta analisis hasil penelitian dapat disimpulkan sebagai berikut

Sejak Januari 2014 Program JKN/KIS yang diselenggarakan BPJS Kesehatan sudah berjalan. meskipun program itu memudahkan masyarakat mengakses pelayanan kesehatan, tapi sampai saat ini pelaksanaanya belum sempurna. Masih ada warga yang mengelukan pelayanan BPJS kesehatan, mereka masih kesulitan mendapatkan pelayanan kesehatan di 
Rumah Sakit. Peserta harus berpindah dari Rumah Sakit lain hanya untuk mendapatkan tempat rawat inap.

Permasalah yang selama ini selalu dikeluhkan oleh peserta BPJS adalah pelayanan dari mitra BPJS. Tidak maksimalnya pelayanan kesehatan dari mitra kerja menjadi salah satu prioritas permasalahan yang dicari solusinya. Keluhan terjadi baik dari fasilitas kesehatan tingkat pertama maupun lanjutan. Keluhan yang terkait dengan Rumah Sakit beragam. Mulai ditolaknya pasien dengan dalih ruang pelayanan penuh hingga perbedaan perlakuan antara pasien peserta BPJS dengan pasien umum. Dan ini menjadi kesan yang buruk terhadap Rumah Sakit sebagai pemberi pelayanan kesehatan dan sangat merugikan pasien peserta BPJS yang merasa telah melaksanakan kewajibannya sebagai peserta BPJS kesehatan.

Fasilitas kesehatan yang tidak bekerjasama dengan BPJS Kesehatan harus segera merujuk ke fasilitas kesehatan yang bekerjasama dengan BPJS Kesehatan setelah keadaan daruratnya teratasi dan pasien dalam kondisi dapat dipindahkan. $^{23}$

Didalam lampiran $\mathrm{Bab}$ IV Huruf A angka 3 Peraturan Menteri Kesehatan Nomor 40 Tahun 2012 tentang Pedoman Pelaksanaan Program Jaminan Kesehatan Masyarakat, disebutkan bahwa pada keadaan gawat darurat (emergency), seluruh fasilitas kesehatan baik jaringan Jaminan Kesehatan Masyarakat ("Jamkesmas") atau bukan, wajib memberikan pelayanan penanganan pertama kepada peserta Jamkesmas. Bagi fasilitas kesehatan yang bukan jaringan Jamkesmas, pelayanan tersebut merupakan bagian dari fungsi sosial fasilitas kesehatan, selanjutnya fasilitas kesehatan tersebut dapat merujuk ke fasilitas kesehatan jaringan fasilitas kesehatan Jamkesmas untuk penanganan lebih lanjut. Berarti meskipun suatu rumah sakit (sebagai fasilitas kesehatan) tidak bekerja sama dengan BPJS Kesehatan, rumah sakit tidak boleh

\footnotetext{
${ }^{23}$ Ibid, Pasal 63 ayat (4).
} 
menolak pasien dalam keadaan darurat dan wajib memberikan pelayanan penanganan pertama kepada pasien peserta BPJS Kesehatan. Karena pelayanan tersebut merupakan bagian dari fungsi sosial fasilitas kesehatan. Setelah keadaan darurat teratasi dan pasien dalam kondisi dapat dipindahkan, fasilitas kesehatan tersebut harus segera merujuk ke fasilitas kesehatan yang bekerja sama dengan BPJS Kesehatan. $^{24}$

Dengan dasar hukum dari pasal-pasal tersebut diatas, maka jika terjadi pelanggaran akan dikenakan sanksi pidana yang mengacu pada Pasal 190 ayat (1) dan ayat (2) Undang-Undang Nomor 36 Tahun 2009 Tentang Kesehatan. ${ }^{25}$

Dengan kedudukan rumah sakit pada saat sekarang, sangat berbeda jauh dengan kedudukannya terdahulu secara fungsi, kebijakan dan

\footnotetext{
${ }^{24} \mathrm{http}: / /$ static.hukumonline.com

25 Yono Maulana, Alasan RS Swasta Belum Mau Bermitra dengan BPJS, https://kompasiana.com., 14 Juni 2016, 15
}

landasan hukumnya dimana rumah sakit dahulu tidak bisa dimintai tanggung jawab hukum pidana dikarenakan rumah sakit masih dianggap sebagai lembaga sosial (doctrin of charitable immunity) yang apabila diminta tanggung jawab hukum pidana, maka akan mengurangi kemampuan menolong pasien. Tetapi sekarang Rumah Sakitumah Sakit mempunyai kekuatan hukum, hak dan kewajiban yang jelas dilindungi hukum dalam kaitannya dengan fungsi sebagai pemberi pelayanan kesehatan.

Saat ini Rumah Sakit juga dipandang subyek hukum. Berarti, Rumah Sakit dapat melakukan hubungan hukum dengan subyek hukum lainnya dalam melaksanakan pelayanan kesehatan. Karena itu Rumah Sakit wajib menanggung segala konsekuensi hukum yang timbul sebagai akibat dari perbuatannya atau perbuatan orang lain yang berada dalam tanggung jawabnya. Tanggung jawab hukum tersebut meliputi tiga aspek yaitu hukum perdata, hukum administrasi 
dan hukum pidana. Dari sisi hukum perdata, pertanggungjawaban Rumah

Sakit terkait dengan hubungan hukum yang timbul antara pasien dengan Rumah Sakit dalam pelayanan kesehatan.

\section{Mengingat Rumah Sakit} adalah organisasi penyelenggara pelayanan publik, dimana segala aktifitas didalamnya mempunyai tanggung jawab publik juga atas setiap pelayanan jasa publik kesehatan yang diselenggarakannya. Tanggug jawab publik Rumah Sakit yaitu menyelenggarakan pelayanan kesehatan yang bermutu, terjangkau, berdasarkan prinsip aman, menyeluruh, non diskriminatif, partisipatif dan memberikan perlindungan bagi masyarakat sebagai pengguna jasa pelayanan kesehatan (health receiver) demi untuk mewujudkan derajat kesehatan yang setinggi-tingginya.

Sedangkan dasar hukum pertanggungjawaban Rumah Sakit dalam pelayanan kesehatan terhadap pasien yaitu adanya hubungan antara Rumah sakit sebagai penyelenggara pelayanan kesehatan, dan pasien sebagai pengguna pelayanan kesehatan. Hubungan hukum tersebut lahir dari sebuah perikatan atau perjanjian tentang pelayanan kesehatan. Sedangkan untuk pelaksaaan perjanjian itu sendiri harus dilaksanakan dengan itikad yang baik sesuai dengan ketentuan Pasal 1338 dan 1339 KUH Perdata, maka proses terhadap kepastian perlidungan hukum bagi pasien dan Rumah sakit jelas.

Disini pasien dilindungi hakhaknya, sebagaimana dalam Pasal 32 huruf c Undang-Undang Republik Indonesia Nomor 44 Tahun 2009 Tentang Rumah Sakit dijelaskan setiap pasien mempunyai hak memperoleh layanan yang manusiawi, adil, jujur dan tanpa diskriminasi. Hak-hak pasien juga dijelaskan didalam Undang-Undang Nomor 23 Tahun 1992 Tentang Kesehatan. Didalam Pasal 14 mengungkapkan bahwa setiap orang berhak untuk mendapatkan kesehatan optimal, sedangkan di Pasal 53 menyebutkan bahwa setiap pasien berhak 
Ariawan Gunadi \& Ida Nursida

mendapatkan informasi, rahasia kedokteran dan hak opini kedua. Pasal 55 menyebutkan bahwa setiap pasien berhak mendapatkan ganti rugi karena kesalahan dan kelalaian petugas kesehatan.

Berdasarkan uraian diatas, penulis memberikan saran-saran sebagai berikut:

\section{Untuk Pemerintah}

a. Pemerintah

perlu

menyinergikan peraturan yang ada, peraturan yang tidak memberatkan salah satu pihak sehingga pihak yang merasa diberatkan tersebut merasa dirugikan dan pihak lain mendapat keuntungan. Pemerintah juga perlu mengajak pihak stakeholder Rumah Sakit swasta untuk duduk berdampingan membicarakan kendala yang menyebabkan pihak Rumah Sakit swasta enggan untuk bekerja sama dengan BPJS Kesehatan.

b. Tidak ada sanksi yang memikat dari pemerintah terhadap
Rumah Sakit-Rumah Sakit swasta, karena Peraturan Presiden Nomor 19 Tahun 2016 tersebut, yang menguraikan bahwa yang menangani pasien BPJS adalah Rumah Sakit pemerintah bukan swasta.

c. Perlu adanya kajian ulang terhadap Permenkes Nomor 59 Tahun 2014, terutama ketentuan yang mengatur tarif INA-CBGs dengan mengacu pada Pasal 24 ayat (1) UndangUndang Nomor 40 Tentang SJSN yang mengamanatkan besaran pembayaran kepada fasilitas kesehatan (faskes) untuk setiap wilayah ditetapkan berdasarkan kesepakatan antara BPJS dan asosiasi fasilitas kesehatan diwilayah tersebut sehingga ada kesepakatan didalam menentukan tarif INACBGs yang selama ini ada penekanan sepihak dari pihak pemerintah. Pembayaran klaim ke Rumah Sakit dari BPJS yaitu maksimal 15 hari kerja menjadi 
kendala terganggunya cash flow Rumah Sakit.

d. Menteri Kesehatan diharapkan terus secara intensif mengajak Rumah Sakit- Rumah Sakit swasta untuk secara terbuka bekerja sama dengan BPJS Kesehatan. Seperti membahas persamaan atau kenaikan tarif INA-CBGs yang dianggap pihak Rumah Sakit swasta masih rendah, tidak memberikan profit dan tidak sebanding dengan kapital yang selama ini diusahakan sendiri, sehingga cost nya lebih tinggi dibandingkan dengan cost Rumah Sakit pemerintah yang semua bebannya ditanggung oleh negara.

e. Sesuatu yang mungkin pihak pemerintah perlu meninjau kembali dalam hal insentif pajak untuk Rumah Sakit swasta, seperti insentif pajak pembelian alat kesehatan, sehingga Rumah Sakit swasta bisa mengalihkan insentif itu untuk biaya pelayanan pasien BPJS kesehatan.

\section{Untuk Rumah sakit}

a. Rumah Sakit harus mengutamakan keselamatan pasien. Untuk keselamatan pasien ini diatur didalam Undang-Undang Nomor 44 Tahun 2009 Tentang Rumah Sakit yang menentukan standar keselamatan pasien.

b. Rumah Sakit sebagai salah satu fasilitas kesehatan kesehatan

c. dilarang menolak pasien dalam keadaan darurat, serta wajib memberikan pelayanan untuk menyelamatkan nyawa pasien. Sesuai Pasal 32 Undang-Undang Nomor 36 Tahun 2009 Tentang Kesehatan (UU Kesehatan). Pimpinan Rumah sakit atau tenaga kesehatan yang menolak pasien yang berada dalam keadaan darurat, dapat dipidana penjara dan dikenakan denda 
Ariawan Gunadi \& Ida Nursida

sebagaimana diatur dalam

Pasal 190 Undang-Undang

Nomor $36 \quad$ Tahun

2009Tentang Kesehatan ayat

(1) dan ayat (2).

d. Tidak adanya pembatasan kuota rawat inap terhadap pasien peserta BPJS Kesehatan, jika perlu harusnya ada penambahan tempat tidur agar tidak terjadi penumpukan pasien atau terjadi waktu tunggu terhadap pasien.

e. Untuk Rumah Swasta seharusnya segera bermitra dengan BPJS Kesehatan karena akan adanya target kesehatan cakupan semesta (universal health coverage) pada 2019, yakni seluruh penduduk Indonesia ikut dalam program BPJS Kesehatan. Jika tidak dikhawatirkan pihak Rumah Sakit swasta tidak dapat pasien.

\section{IV.DAFTAR PUSTAKA}

\section{A. BUKU}

Suharto. Edi, Kemiskinan dan Perlindungan Sosial di Indonesia, Menggagas Model JaminanSosial Universal Bidang Kesehatan., Bandung:Alfabeta, 2009.

Syahrul Machmud, Rumah Sakit Sebagai Penyelenggara

Pelayanan Publik, Jakarta: Raja Grafindo Perkasa, 2012.

Wila Chandrawila Supriadi, Hukum Kedoktean, Bandung: Mandra Maju, 2001.

\section{B.PERUNDANG-UNDANGAN}

— Undang-Undang Dasar 1945.

- Undang-Undang Nomor 24 Tahun 2011 Tentang Badan Penyelenggara Jaminan Sosial.

- Undang-Undang Nomor 36 Tahun 2009 Tentang Kesehatan

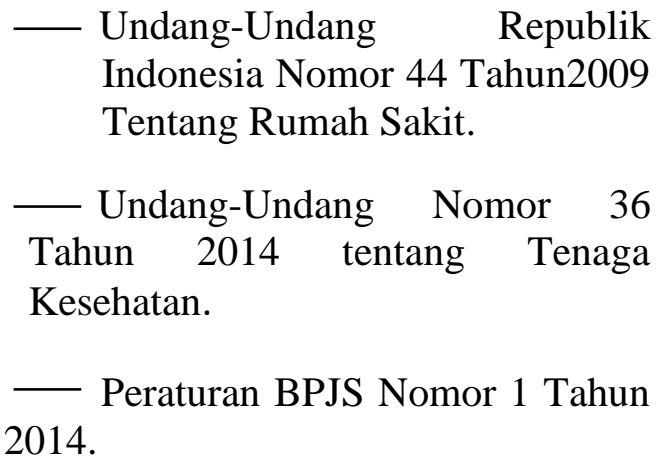


-Undang-Undang Nomor 40 Tahun 2004 Tentang.

\section{INTERNET/ARTIKEL}

http://static.hukumonline.com

Yono Maulana, Alasan RS

Swasta Belum Mau Bermitra

dengan

BPJS,

https://kompasiana.com., $\quad 14$ Juni 2016.

Yoga Sukmana, $R S$ Kerap Bilang Ruangan Penuh untuk Pasien BPJS, Ini Penjelasan Ombudsman, Kompas.com, 2017.

Sucipto Kuncoro, http://dinkes.jakarta.go.id/

Senin (11/9/2017). 